\title{
Development of Interactive Learning Media Flip-Book Using Kvisoft Flipbook Maker Based on Local Culture Arts
}

\author{
Reni Ariska Putri ${ }^{1}$ \\ Sri Uchtiawati ${ }^{2}$ \\ Nur Fauziyah ${ }^{3}$ \\ Syaiful Huda ${ }^{4}$ \\ 1,2,3,4 Universitas Muhammadiyah Gresik Indonesia \\ 1 putrireniariska@gmail.com \\ 2 sri.uchtiawati@umg.ac.id \\ 3 nurfauziyah@umg.ac.id \\ syaifulhuda@umg.ac.id
}

\begin{abstract}
ABSTRAK
Pengembangan media pembelajaran interaktif flipbook menggunakan kvisoft flip book maker berbasis seni budaya lokal adalah salah satu cara dalam memanfaatkan tekonologi pendidikan berupa software kvisoft flip book maker yang dipadukan dengan seni budaya lokal dan dihasilkan suatu produk pengembangan berupa media pembelajaran matematika flip book. Tujuan dalam penelitian ini untuk mengetahui proses pengembangan media pembelajaran flip book dan efektifitas media pembelajaran flip book dalam proses pembelajaran di kelas. Subjek dalam penelitian ini adalah 30 orang peserta didik yang terdiri dari 16 laki-laki dan 14 perempuan kelas VII sekolah menengah pertama di Indonesia. Model pengembangan dalam penelitian ini menggunakan model $4 D$ yang terdiri dari tahapan define, design, develop, dan disseminate. Proses pengembangan dalam penelitian ini dimulai dari tahap define dengan melakukan analisis awal akhir, analisis peserta didik, analisis tugas, analisis konsep, dan spesifikasi tujuan pembelajaran; tahapan selanjutnya adalah tahap design dengan melakukan penyusunan tes acuan patokan, pemilihan media, pemilihat format, dan rancangan awal media; tahapan selanjutnya adalah tahap develop dengan melakukan validasi ahli dan uji pengembangan; dan tahapan terakhir adalah tahap disseminate dengan melakukan pengemasan media dan penyebaran media pada lingkup sekolah yang sama dengan kelas yang berbeda. Pengembangan media pembelajaran flip book ini dapat menjadi alternatif pilihan dalam penggunaan media pembelajaran matematika, khususnya pada materi aritmatika sosial.
\end{abstract}

Kata Kunci : media, pembelajaran, Flifbook

\begin{abstract}
Development of interactive learning media flip book using Kvisoft flipbook maker based on local culture and art is one way to utilize technology education in the form of software kvisoft flipbook maker which is integrated with local cultural arts and produced a development product in the form of learning media for mathematics flip book. The purpose of this study was to determine the process of developing flip book learning media and the effectiveness of learning media flip book in the learning process in class. The subjects in this study were 30 students consisting of 16 men and 14 women in grade VII junior high school in Indonesia. The development model in this study uses the 4D model which consists of the stages of define, design, develop, and disseminate. The development process in this study starts from the stage define by conducting initial initial analysis, student analysis, task analysis, concept analysis, and learning objective specifications; the next stage is the stage design by conducting a benchmark reference test, media selection, format, and initial media design; the next stage is the stage develop by conducting expert validation and development testing; and the last stage is the stage disseminate by packaging media and distributing media in the same school scope
\end{abstract}


with different classes. The development of this learning media flip book can be an alternative choice in the use of mathematics learning media, especially in social arithmetic material.

\section{Keywords: Media, Learning, Flip-Book}

\section{INTRODUCTION}

In the secondary Problems in mathematics education that are often faced by students is that mathematics is a difficult and unpleasant subject, even a frightening specter. Causing students to dislike mathematics. Even though mathematics is considered to have a high level of difficulty, everyone must learn it because it is a means of solving everyday problems. Mathematics is also a component of a series of subjects that have an important role in education (Sundayana, 2015).

Mathematics has an important role in education. For this reason, efforts are needed to overcome these problems, one of which is by using learning media. In the learning process, the use of instructional media in the teaching and learning process is intended to overcome learning difficulties and facilitate instructional activities (Bustari, 2005). Learning media in the classroom need not only be in the form of textbooks but rather broader than that. Some lack textbook media, "for example; not "alive", only presents dead images, unable to present sound, and is easily outdated (Schramm, 1984) in (Rasiman, 2014).

Learning Media can also be obtained through the use of educational technology. In this modern era, technology has many types and uses. One type of educational technology is the use of software computer. Kvisoft Flip book Maker is software for making e-books. Students can read by feeling like opening a book physically because there is an animation effect where when moving pages will look like opening a book physically (Syarif \& Rakhmawati, 2016).

Flip book is a multimedia-based learning media that can be used in the process of learning mathematics. In grade VII junior high school there is some material in mathematics. One of them is social arithmetic material.
Questions on social arithmetic material to make it more interesting to study can be combined with local cultural arts. Some of the cultural arts, crafts and local specialties that are used as a blend in this study are woven sarong, skull cap, embroidery, pudak, brains of milkfish, jambungan, nasi krawu, damar brackets, damar brackets paintings, and milkfish markets.

The wealth of local cultural arts is very appropriate to be introduced to the world, especially the world of mathematics education. The combination makes students not only interested in learning with the media and learning mathematical material, but also students will get to know and learn about the arts and culture, crafts and local specialties, in order to preserve local cultural arts, crafts and food. Education based on culture requires social institutions, such as families and schools, to be the center of local and national cultural development (Martono, 2011).

Development research can be used as a basis for producing this interactive learning media product. The development model in this study uses the 4D model which consists of the stages of define, design, develop, and disseminate. Research and development or Research and Development (R \& D) is a strategy or method of research that is powerful enough to improve practices and is a process or steps to develop a new product or improve existing products, that can be justified (Sukmadinata 2010 ).

In fact, so far the learning process still uses conventional learning models that place the teacher as the main source of information that plays a dominant role in the learning process (Rasiman, 2014). So the use of mathematics learning media that utilizes software computer can be an alternative choice and can help 
students in learning mathematics material, especially material arithmetic social.

\section{LITERATURE REVIEW}

\section{Interactive Learning Media Learning}

Media always consists of two important elements, namely elements of equipment or hardware and software. Software is information or teaching material itself that will be delivered to students, while hardware is a means or equipment used to present the message / teaching material. Thus learning media needs equipment to present messages, but the most important thing is not the equipment, but learning messages or information delivered by the media (Susilana \& Riyana, 2009).

The characteristics of interactive learning media are that students not only pay attention to the media or objects, but also required to interact while following the learning. There are three types of interactions, namely: (1) which shows students interacting with a program, for example students are asked to fill in blanks on programmed learning material, (2) students interact with machines, such as machine learning, simulators, language laboratories, computers, or a combination of them in the form of interactive videos, (3) regulates interactions between students on a regular but not programmed basis, for example, can be seen in various educational games or simulations involving students in activities or problems, which require them to collaborate with teammates in solving problems. Therefore, teachers consider it as the best source of learning in matters of communication media (Susilana \& Riyana, 2009).

\section{Kvisoft Flip Book Maker Software Kvisoft}

Flipbook maker is a software for making ebooks, e-modules, e-paper and e-magazines. Not only in the form of text, with Kvisoft Flipbook Maker can insert pictures, graphics, sound, links and videos on worksheets. The application used in this study is Kvisoft Flipbook Maker Pro 4.3.3. In general, thistool software can insert filesthe inform of PDFs, images, videos and animations so that the flip book is made more attractive, besides that, Kvisoft Flipbook Maker has a design template and features such as background, control buttons, navigation bar, hyperlink and backsound. Students can read by feeling like opening a book physically because there is an animation effect where when moving pages will look like opening a book physically. The final result can be saved to formats html, exe, zip, screen saver and app(Syarif \& Rakhmawati, 2016).

\section{Flip Book}

Flip book is a classic animation made from a stack of paper resembling a thick book, on each page a process is described about something that later the process looks animated (Diena \& Heri, 2010).

Flip book is one of the classic animation types made from paper masses resembling thick books, on each page a process is described about something that later the process is seen moving or animated (Manivannan \& Manian, 2011)

\section{Art Culture}

Art was originally a process from humans, and therefore it is a synonym of science. Art can be seen in the essence of expression of human creativity. Art can also be interpreted with something created by humans that contains elements of beauty.

Art according to the media used is divided into three, namely: (1) Art that can be enjoyed through the media of hearing or (audio art), for example music art, sound art, and literary arts such as poetry and rhymes, (2) Art enjoyed with media of vision ( visual art) for example paintings, posters, building art, martial arts and so on, and (3) Art that is enjoyed through visual and auditory media (audio visual art) such as musical performances, puppet shows and films (Harris, 2014).

Culture is as a social value or practice that is applicable and exchanged in human relations 
both as individuals and members of society (Nasrullah, 2014: 18).

\section{Development of Instructional Media}

Research and development or Research and Development (R \& D) is a strategy or method of research that is powerful enough to improve practices and is a process or steps to develop a new product or improve existing products, which can dipertanggung answer (Sukmadinata, 2010). Another opinion says development research is research directed to produce products and designs (Setyosari, 2012).

Systematic and systemic processes in designing learning activities generally use a certain model form. A model basically describes the sequence or activities carried out as a whole to create a learning process. In connection with that there are a number of development models proposed by experts, namely: the Dick and Carey Model, the Jerold E. Kemp Model, the ADDIE Model, the ASSURE Model and the 4D Model. (Personal, 2011).

The development model in this study uses the 4D model which consists of the stages of define, design, develop, and disseminate. This model was developed by Sivasailam Thiagarajan, Dorothy S. Semmel, and Melvyn I. Semmel (Trianto, 2013).

\section{METHODE}

\section{Subject}

This research was conducted at a State Junior High School in Indonesia in the even semester of the academic year 2017/2018. The material in this study is social arithmetic material class VII junior high school. The subjects in this study were eighth grade students with 30 students consisting of 16 men and 14 women.

\section{Research Procedure}

The Interactive learning media development model flip book on social arithmetic material refers to the development model developed by Sivasailam Thiagarajan, Dorothy S. Semmel, and Melvyn I. Semmel, the 4D model. The stages are Define, Design, Develop and Disseminate (Trianto, 2013).

Phase Define: begins by conducting the initial initial analysis to establish the basic problems needed in the development of instructional media. At this stage interviews and observations were made to one of the mathematics teachers; then analyzing students, by distributing students learning style questionnaires to find out the characteristics of students' learning styles; next task analysis, identify the tasks or key skills that students do during learning; then the concept analysis is aimed at identifying, detailing and systematically compiling relevant concepts that will be taught; and finally the specification of learning objectives, this stage is carried out to formulate the results of task analysis and concept analysis to be indicators of achievement of learning outcomes which will be elaborated and contained in the syllabus and Learning Implementation Plan (RPP).

Stage Design: at this stage the researcher carries out a benchmark reference test. This test is a step that connects the definition stage with the design stage. Benchmark reference tests are prepared based on the specifications of learning objectives and analysis of students; then selecting media, to identify learning media that are relevant to the characteristics of the material; then selecting the format, intended to choose the type of media, design or design the contents, selection of strategies, approaches, learning methods and learning resources for learning media flipbook ; and finally the initial design, namely the design of all learning media that must be done before the trial is carried out, namely the creation of interactive learning media flip book and the preparation of research instruments.

Phase Develop: at this stage learning media validation is carried out flipbook to media experts and material experts. The assessment of material experts on instructional media includes: format, content and language, and the assessment of media experts on instructional media includes: simplicity, 
cohesiveness, emphasis, balance, shape, and color; then based on the input and evaluation of media experts, it can be improved more precisely, effectively, easily used and has high technical quality. And further development tests will be conducted to obtain direct input in the form of responses, reactions, comments from students and observers to the learning media that have been prepared.

Phase Disseminate: at this stage the packaging of media is carried out learning flipbook into CDs and making CD covers and distributing them to other classes at the same school.

\section{Data Collection Method}

This research uses four methods of data collection to address problems regarding the design of interactive learning media development flip book, the quality of interactive learning media results flip book and the effectiveness of product development, namely the method of recording documents, questionnaires, tests, and observations.

\section{Research Instruments}

The research instruments in this study consisted of the student learning style questionnaire sheet, the student response questionnaire sheet, the practical practicing media questionnaire sheet, thesheet validation learning media expert, the test questions, and the student activity observation sheet.

\section{Data Analysis Method}

Data obtained in this study were then analyzed and used as a basis for revising the interactive learning media flipbook. The analysis consists of qualitative descriptive analysis, quantitative descriptive analysis, and inferential statistical analysis.

Quantitative descriptive analysis is a way of analyzing or processing data by systematically compiling in the form of sentences / words, categories regarding a subject (objects, symptoms, certain variables), so that finally a general conclusion is obtained
(Agung, 2010). This analysis is used to process data from interviews, students' initial knowledge and practicality of instructional media.

Quantitative descriptive analysis is a way of processing data that is done by systematically compiling in the form of numbers or percentages, regarding an object under study, in order to obtain general conclusions (Agung, 2010). This analysis is used to process student learning style questionnaire data results and validity sheets of learning media.

Inferential statistical analysis is used to determine the level of effectiveness of the product on the learning outcomes of students in grade VII students after using the interactive media learning media development product flip. Analysis of the effectiveness of interactive learning media flip book consists of classical learning completeness analysis of learners,learner response questionnaire analysis, and analysis of the activity of learners.

\section{RESULTS AND DISCUSSION}

The process and research results of interactive media development flip book using the 4D development model are as follows:

Phase Define: there are several stages of analysis namely, initial initial analysis, student analysis, task analysis, concept analysis, and specification of learning objectives.

The initial initial analysis, based on the results of interviews with mathematics subject teachers found that students were said to be able to operate computers. The attitude of students towards mathematical material differs between men and women, male students are only partially enthusiastic when learning mathematics takes place. Conversely female students behave positively when learning mathematics takes place. And the results obtained are that gender and age susceptibility that dominate VII grade State Junior High School in a district in Indonesia, there are 16 male students and 14 female students with age around 13-14 years. 
Analysis of students, from the results of the distribution of the learning style questionnaire obtained the results that 10 students have a visual learning style, 8 students have an auditory learning style, 12 students have a kinesthetic learning style.

Task analysis, based on the analysis obtained the results that students prefer to associate learning material with events or events in life everyday. In the development of interactive learning media flipbooks this material determined is social arithmetic material.

Concept analysis, based on the analysis shows that students are more happy to formulate mathematical formulas in a symbol or picture. In the development of this interactive learning media flipbook the concepts of social arithmetic material relating to sales, purchases, deductions, profits, losses, single interest, percentages, gross, net, tare are related to local cultural arts and the formulas are formulated in a symbol or picture.

Specification of learning objectives, from the results of discussions with mathematics subject teachers obtained learning objectives that are used as the basis in the preparation of learning media flipbook, namely students are able to: analyze social arithmetic (sales, purchases, deductions, profits, losses, single interest, percentages, gross, net, tare); solving problems related to social arithmetic (sales, purchases, deductions, profits, losses, single interest, percentages, gross, net, tare) and more explained in the syllabus and lesson plans.

Stage Design: there are several stages, namely the preparation of reference tests, media selection, format selection and initial media design.

The preparation of the reference test, at this stage, a benchmark reference test is carried out before using the interactive learning media flipbook. The test questions consist of 10 multiple choice questions. Scoring the test results using an evaluation guide that contains keys and scoring guidelines for each item. Based on the tests carried out, the average results obtained by students are still below the specified KKM which is still below 70 .

Selection of media, the selection process is adjusted to the learning objectives and characteristics of students. Such as collecting literacy or literature that is relevant to social arithmetic material, namely the VII grade junior high school mathematics textbook published by the ministry of education and culture (revised edition 2016), and collecting softwares used for making interactive learning media flip book such as, kvisoft flip book maker pro 4.3.3.0, quiz maker, videoscribe, FLV converter, flash video encoder, and microsoft word 2010.

Format selection, the selection process is done by designing the front cover of the flip book, designing the display on each sheet of flip book, designing a video display that explains about social arithmetic figures, designing back covers flipbook, designing contents flipbook, and choosing the musical instrument used on the flip book which is a cheerful music instrument.

Initial design, at this stage the researchers began to design learning media flipbook by making the initial contents Flip Books are done in Microsoft Word 2010. After the design is complete, it is created in the form of a word document and then converted to PDF. Then implemented in software kvisoft flip book maker, and the selection of templates according to age and sex, editing process is carried out on the media by entering the video and sound instruments needed. In this stage, a temporary design of learning media was produced flip book. At this stage also made research instruments such as the validity of the learning media flipbook, the questionnaire practicality of the learning media flipbook questionnaire, the student response questionnaire, the student observation sheet and the making of the quiz with the help of quiz maker software.

Stage Develop: there are several stages, namely expert validation and development testing.

Expert validation, at this stage an expert validation was carried out on the learning media 
flip book created. Expert validation included material expert review, media expert(designdesign), instructional media expert review (practicality).

Material expert validation, This validation is used to obtain data on the level of validity of the material being developed. Based on expert assessment of the material,learning media flipbook have very good qualifications with a percentage of $92 \%$ and do not need revision.

Media expert validation, This validation is used to obtain data on the level of media validation developed. Based on the assessment of media experts,learning media flipbook has very good qualifications with a percentage of $96.36 \%$ and does not need revision. So based on the two assessments from the material experts and media experts it can be concluded the assessment for learning media flipbook has a very good qualification with a percentage of $94.18 \%$ and does not need revision.

Table 1: Media Validation

\begin{tabular}{|c|c|c|c|}
\hline \multicolumn{2}{|c|}{ Penilaian Vabidator Materi } & \multicolumn{2}{|c|}{ Peuilaian Validater Media } \\
\hline $\begin{array}{l}\text { Jumlah Skot yang } \\
\text { Didapat }\end{array}$ & 69 & $\begin{array}{l}\text { Jumlah Skor ymg } \\
\text { Didapat }\end{array}$ & 53 \\
\hline Persentase & $92 \%$ & Periscatase & 96,3696 \\
\hline Kualifikasi & $\begin{array}{l}\text { Sangat } \\
\text { Baik }\end{array}$ & Kualifikasi & $\begin{array}{l}\text { Sangat } \\
\text { Baik }\end{array}$ \\
\hline Keterangan & $\begin{array}{l}\text { Tidak } \\
\text { Pertu } \\
\text { Revisi }\end{array}$ & Keterangan & $\begin{array}{l}\text { Tidalk } \\
\text { Perlu } \\
\text { Revisi }\end{array}$ \\
\hline \multicolumn{2}{|l|}{ Persentase akdir } & \multicolumn{2}{|l|}{$94,18 \%$} \\
\hline \multicolumn{2}{|l|}{ Kitalifikasí } & \multicolumn{2}{|l|}{ Sangat Bail: } \\
\hline \multicolumn{2}{|l|}{ Keterangan } & \multicolumn{2}{|l|}{ That Pertu Revidi } \\
\hline
\end{tabular}

Assessment of the practicality of learning media flipbook, assessment this is used to obtain data on the practicality of learning media flipbook.

Table 2: Assessment of the practicality of instructional media

\begin{tabular}{|c|c|c|c|}
\hline No. & Nama Alit & $\begin{array}{c}\text { Penilaian } \\
\text { secara umum }\end{array}$ & Keterangan \\
\hline 1. & Midjan, M.Pd. & A & $\begin{array}{c}\text { Dapat } \\
\text { digunakan tampa } \\
\text { revisi }\end{array}$ \\
\hline 2. & $\begin{array}{c}\text { Hj. Aries Tuningsih, } \\
\text { S.Pd. }\end{array}$ & A & $\begin{array}{c}\text { Dapat } \\
\text { digunakan tanpa } \\
\text { revisi }\end{array}$ \\
\hline
\end{tabular}

From the results of the study in general, it was found that the learning media is flip book practical and can be used in the learning process.

Development test, at this stage there are several stages that are carried out such as, the stage of development testing in class, the stage of asking students for responses, and the evaluation stage.

Development Test Phase in the class, at this stage the development test was carried out in a class VII State Junior High School in a district in Indonesia. This development test is to obtain data about the effectiveness of the developed media. Due to time constraints approaching the UNBK (National ComputerBased Examination) SMP, researchers were unable to use computer laboratories for development testing and also because of the limited laptops they have (4 laptops), the development test was carried out in rotation. But before conducting the development test, researchers conducted several activities namely, preparing learning tools, preparing time, and preparing students. In conducting the development meeting of the first meeting, researchers prepared a laptop used for the development test. Researchers installed 3 laptops that had not been installed learning media flip book. After installing, the researcher asks students to form into 4 groups and learning activities are carried out using learning media flipbook. The second meeting was used to briefly explain social arithmetic material by researchers and evaluation activities.

During the process of implementing the development test, observations were made of the activities of students while participating in mathematics learning using learning media flipbook. Observations were made by mathematics subject teacher and 1 student colleague for 2 times according to the number of meetings, from the results of the percentage of all meetings, it was found that the average percentage of all meetings on active criteria reached $74.84 \%$ or more than $50 \%$. 
Table 3: Result of Observation

\begin{tabular}{|c|c|c|c|c|c|c|}
\hline \multirow[b]{2}{*}{$\begin{array}{l}\text { Aluivitas } \\
\text { Ke }\end{array}$} & \multicolumn{3}{|c|}{ Pestemuan Ke-1 } & \multicolumn{3}{|c|}{ Peiteinusan K.:-2 } \\
\hline & Altaif & $\begin{array}{c}\% \\
\text { Culup } \\
\text { Aknif }\end{array}$ & $\begin{array}{l}\% \\
\text { Tidak } \\
\text { Akuif }\end{array}$ & Alaif & $\begin{array}{c}\text { \%e } \\
\text { Cubay } \\
\text { Aktir }\end{array}$ & $\begin{array}{c}\% \\
\text { Thiak } \\
\text { Aktir }\end{array}$ \\
\hline 1 & $\begin{array}{c}93,34 \\
96\end{array}$ & $6,67 \%$ & $0 \%$ & $\begin{array}{c}96,67 \\
\%\end{array}$ & 3,3496 & $0 \%$ \\
\hline 2 & $\begin{array}{c}66,67 \\
\%\end{array}$ & $\begin{array}{c}28,34 \\
96\end{array}$ & $5 \%$ & $90 \%$ & 6,6796 & $\begin{array}{c}3,34 \\
96\end{array}$ \\
\hline 3 & $\begin{array}{c}78,34 \\
96\end{array}$ & $\begin{array}{c}18,33 \\
4\end{array}$ & $3,34 \%$ & $65 \%$ & $\begin{array}{c}23,33 \\
46\end{array}$ & $\begin{array}{c}11,67 \\
96\end{array}$ \\
\hline 4 & $\begin{array}{c}58,33 \\
\%\end{array}$ & $\begin{array}{c}33,34 \\
96\end{array}$ & $8,34 \%$ & $\begin{array}{c}91,67 \\
96\end{array}$ & $8,34 \%$ & $0 \%$ \\
\hline 5 & $55 \%$ & $\begin{array}{c}26,67 \\
96\end{array}$ & $\begin{array}{c}18,35 \\
36\end{array}$ & $\begin{array}{c}53,34 \\
9\end{array}$ & $\begin{array}{c}26,67 \\
4\end{array}$ & $20 \%$ \\
\hline $\begin{array}{l}\text { Persentase } \\
\text { rata-rata }\end{array}$ & $\begin{array}{c}70,34 \\
6\end{array}$ & $\begin{array}{c}22,67 \\
\%\end{array}$ & 76 & $\begin{array}{c}79,34 \\
6\end{array}$ & $\begin{array}{c}13,67 \\
6\end{array}$ & 76 \\
\hline \multirow{3}{*}{\multicolumn{3}{|c|}{$\begin{array}{l}\text { Rata-rata Persentase Seburuh } \\
\text { Pertermasan }\end{array}$}} & \multicolumn{2}{|l|}{$\because$ Aktif } & \multicolumn{2}{|c|}{$74.84 \%$} \\
\hline & & & \multicolumn{2}{|c|}{ •Calasp Aktir } & \multicolumn{2}{|c|}{$18,17 \%$} \\
\hline & & & \multicolumn{2}{|c|}{ - Tidak Aktif } & \multicolumn{2}{|c|}{$7 \%$} \\
\hline
\end{tabular}

Stage asks students responses,

Table 4: Student Responses

\begin{tabular}{|c|c|c|c|}
\hline Na. Aspek & Z sker & Persentase & Kriteria \\
\hline 1 & 128 & $35,33 \%$ & Baik \\
\hline 2 & 121 & 80,6796 & Baile \\
\hline 3 & 134 & 89,3396 & Baik \\
\hline 4 & 131 & 87,3396 & Bafl \\
\hline 5 & 130 & $86,67 \%$ & Baik \\
\hline 6 & 138 & $92 \%$ & Sangat Bail \\
\hline 7 & 137 & 91,3396 & Sangat Hailk \\
\hline 8 & 127 & $84,67 \%$ & Baik \\
\hline 9 & 125 & $83,33 \%$ & Bsik: \\
\hline 10 & 133 & 88,679 & Baik \\
\hline 11 & 230 & 88,6796 & Baik \\
\hline 12 & 128 & 85,3396 & Baik \\
\hline 13 & 130 & $86,67 \%$ & Baik: \\
\hline 14 & 118 & $78,67 \%$ & Crikup Brik \\
\hline 15 & 141 & $94 \%$ & Sangat Baik \\
\hline \multicolumn{2}{|c|}{$\begin{array}{l}\text { Rata-rata Respen Pvoerta } \\
\text { didike }\end{array}$} & $86,95 \%$ & Baik \\
\hline
\end{tabular}

Based on the analysis obtained the percentage of students' responses from each aspect and presented is $86.85 \%$.

Evaluation phase, at this stage an evaluation of learning outcomes is carried out by giving questions to students consisting of 10 multiple choice questions and contained one folder on the learning media flipbook. Based on the analysis of the data obtained, the results obtained that the students who got a score of 70 were 24 people and said to be complete, while 6 students were 70 or incomplete. So the classical completeness of students by $80 \%$.
Table 5: Evaluation of Learning Outcomes

\begin{tabular}{|c|c|c|c|c|}
\hline & & & \multicolumn{2}{|c|}{ KRIIERA } \\
\hline & \multirow{2}{*}{ NO INDUK } & NILAI & Tuntas & $\begin{array}{c}\text { Tidak } \\
\text { Tuntas }\end{array}$ \\
\hline 1 & & & & \\
\hline 2 & 12478 & 80 & $\checkmark$ & \\
\hline 3 & 12479 & 90 & $\checkmark$ & \\
\hline 4 & 12481 & 70 & $\checkmark$ & \\
\hline 5 & 12482 & 70 & $\checkmark$ & \\
\hline 6 & 12483 & 100 & $\checkmark$ & \\
\hline 7 & 12484 & 80 & $\checkmark$ & \\
\hline 8 & 12485 & 100 & $\checkmark$ & \\
\hline 9 & 12486 & 80 & $\checkmark$ & \\
\hline 10 & 12487 & 80 & $\checkmark$ & \\
\hline 11 & 12488 & 60 & & $\checkmark$ \\
\hline 12 & 12489 & 50 & & $\checkmark$ \\
\hline 13 & 12490 & 60 & & $\checkmark$ \\
\hline 14 & 12491 & 80 & $\checkmark$ & \\
\hline 15 & 12492 & 70 & $\checkmark$ & \\
\hline 16 & 12493 & 80 & $\checkmark$ & \\
\hline 17 & 12494 & 80 & $\checkmark$ & \\
\hline 18 & 12495 & 80 & $\checkmark$ & \\
\hline 19 & 12496 & 70 & $\checkmark$ & \\
\hline 20 & 12497 & 60 & & \\
\hline 21 & 12498 & 70 & $\checkmark$ & \\
\hline 22 & 12499 & 80 & $\checkmark$ & \\
\hline 23 & 12500 & 70 & $\checkmark$ & \\
\hline 24 & 12501 & 60 & & $\checkmark$ \\
\hline 25 & 12502 & 50 & & $\checkmark$ \\
\hline 26 & 12503 & 70 & $\checkmark$ & \\
\hline 27 & 12504 & 90 & $\checkmark$ & \\
\hline 28 & 12505 & 90 & $\checkmark$ & \\
\hline 29 & 12506 & 80 & $\checkmark$ & \\
\hline 30 & 12507 & 80 & $\checkmark$ & \\
\hline & & & & \\
\hline
\end{tabular}

In this study learning media are flip book said to be effective because they meet 3 requirements, namely (1) Classically $75 \%$ of all learners are complete, (2) In percentage the responses of students obtained are more than or equal to $65 \%$ and said to be quite good, (3) And the number of active students reaches more than $50 \%$. In the previous stage these things have been done, the design temporary learning media is flip book said to be effective and there is no need to make revisions. So that the temporary design is said to be the final design of learning media flip book and is suitable for use.

Phase Disseminate: at this stage the packaging of the learning media is carried out flipbook by moving data into CDs and making CD covers. And spread on a broader scale such as in another class, at another school or another teacher. However, researchers chose to carry out the distribution in different classes at the same school. So the product development 
results can be used and utilized to the maximum in supporting learning.

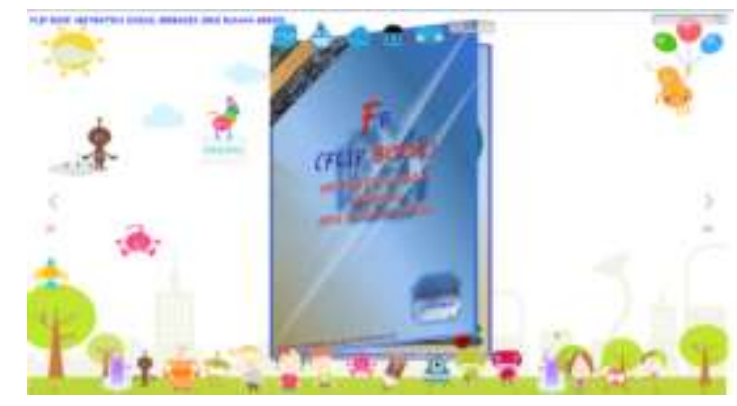

Figure 1: Front CoverLearning Media Flip

Based on the data from the results of this study, the development of learning media flipbook obtained satisfactory results.

The difference in learning media that will be developed by researchers with previous studies are (1) material that will be used as material in the development of learning media, namely social arithmetic material, (2) there is a video display that tells about the short history of social arithmetic figures, (3) there an explanation of the local cultural arts, (4) there are worksheets that are adapted to the scientific approach, (5) social arithmetic questions are associated with local cultural arts, crafts, and foods, (6) there are materials, formulas and examples of questions which can make it easier for students to understand social arithmetic material, (7) this learning media has a test of knowledge or practice questions and evaluation questions in the form of multiple choice quizzes that can provide interaction between users (students) with learning media because it is the output of the quiz maker software ( contained in one media folder).

In developing thismedia flip book, researchers used social arithmetic material. Because based on the results of the study, students are more receptive to mathematical material when the material is linked to the daily lives of students.

The addition of a brief historical video of social arithmetic figures and a combination of social arithmetic problems with local cultural arts is intended so that students not only learn social arithmetic material, but also learn about the history of social arithmetic figures and local cultural arts.

The Media is flip book equipped with knowledge tests and multiple choice questions exercises that can be interactively solved by students, so that students can practice cognitive abilities on social arithmetic material. This is in line with research and media made by previous researchers (Mustakim, Zainul. 2015).

In research conducted by media researchers is flip book made by the presence of videos and questions that can be answered interactively by students. Whereas in previous research,media was flip book only made without a quiz that students could interactively interact with (Habibi, Bayu. 2017).

\section{CONCLUSION}

Based on the results of data analysis that has been done, the answer to the problem formulation which is the conclusion of this research is the development process carried out by researchers to produce interactive learning media, flipbook which are define, design , develop, and disseminate .

In the phase define (definition), researchers set and define the terms of the stages of learning, namely, among others: the end of the preliminary analysis, analysis of learners, task analysis, concept analysis, and specification of learning objectives; at the stage design (design), the researcher designs a development product that is the stages including: preparation of reference tests, media selection, format selection, initial design of media \& research instruments; at the stage develop, the researcher produces a development product, the stages of which include: expert validation, analysis and revision, test development; and at the stage disseminate, the researchers packaged the media and then spread the learning media flip book.

The researcher can also conclude that the effectiveness of the learning media flipbook on research in a VII grade of the SMP Negeri in a 
district in Indonesia is said to be effective. Because it fulfills 3 conditions, namely (1) Classically $75 \%$ of all students are complete, that is $80 \%$, (2) In terms of the percentage of students who got more than or equal to $65 \%$ and said to be good enough that is equal to 86 , $85 \%$, (3) And the number of active students reached more than $50 \%$, namely $74.84 \%$.

\section{REFERENCES}

Agung, A. (2010). Metode Penelitian. Singaraja: Fakultas Ilmu Pendidikan Universitas Pendidikan Ganesha.

Bustari, M. (2005). Pemanfaatan Sumber Belajar dalam Rangka Peningkatan Mutu Sekolah. Jurnal Manajemen Pendidikan No. 1.

Diena, R., \& Heri, S. (2010). Penggunaan Media flash Flip Book dalam Pembelajaran Teknologi Informasi dan Komunikasi untuk Meningkatkan Hasil Belajar Siswa. Jurnal Teknologi Informasi.

Habibi, Bayu. (2017). Pengembangan Media Pembelajaran Interaktif Multimedia menggunakan Kvisoft Flip Book Maker Berbasis Etnomatematika. Skripsi dipublikasikan. Lampung: Program Sarjana (Strata 1) di Universitass Islam Negeri Raden Intan.

Harris, K. (2014). Peran Dinas Kebudayaan dan Pariwisata dalam Pengembangan Seni Budaya di Kabupaten Bulungan. Jurnal Ilmu Pemerintahan No. 01, Vol. 02, 2007.

Manivannan, M., \& Manian, D. (2011). Animation In J2ee Projects-An Overview. Internasional Journal of Graphics Multimedia No. 01, Vol. 02.

Martono. (2011). Peran Pendidikan Seni dalam Pelestarian dan Pengembangan Batik Sebagai Produk Budaya Bangsa. Jurnal Seni, 15.

Mustakim, Zainul. (2015). Pengaruh Penggunaan Multimedia Interaktif Flass Flip Book Terhadap Hasil Belajar Siswa pada Konsep Sistem Pernapasan. Skripsi dipublikasikan. Jakarta: Program Sarjana (Strata 1) di Universitas Islam Negeri Syarif Hidayatullah.

Nasrullah, R. (2014). Komunikasi Antar Budaya di Era Budaya Siber. Jakarta: Kencana Prenadamedia Group.

Pribadi, B. (2011). Gaya Belajar. Dipetik Desember Sabtu, 2017, dari http://prasetyo.files. wordpress.com52f20 $10 \% 2 \mathrm{~F} 10 \% 2$ Ftes-gaya-belajar-anak.docx

Rasiman. (2014). Efektifitas Resource-Based Learning Berbantuan Flip Book Maker Dalam Pembelajaran Matematika SMA. JKPM, 1.

Setyosari, P. (2012). Metode Penelitian Pendidikan dan Pengembangan. Jakarta: Kencana Prenada Media Group.

Sukmadinata, N. (2010). Metode Penelitian Pendidikan. Bandung: Rosya Karya.

Sundayana, R. (2015). Media dan Alat Peraga dalam Pembelajaran Matematika. Bandung: Alfabeta.

Susilana, R., \& Riyana, C. (2009). Media Pembelajaran (Hakikat, Pengembangan, Pemanfaatan, dan Penilaian). Bandung: CV. Wacana Prima.

Syarif, H., \& Rakhmawati, L. (2016). Pengembangan Media Pembelajaran berbasis Flip Book Maker pada Pelajaran Elektrinika Dasar di SMKN 1 Sampang. Jurnal Matematika FMIPA UNNESS No. 02, Vol. 03.

Trianto. (2013). Model Pengembangan Terpadu Konsep Strategi dan Implementasinya dalam Kurikulum Tingkat Satuan Pendidikan (KTSP). Jakarta: PT Bumi Aksara. 